\title{
Institutional Set-Up and Mandates of Macroprudential Authorities: International Experience and Benchmarks for Ukraine
}

\author{
Andriy Danylenko \\ National Bank of Ukraine
}

\author{
Viktoriia Sanzharovska \\ National Bank of Ukraine
}

\begin{abstract}
Defining macroprudential authority is one of the key steps in ensuring financial stability. Within the framework of general principles defined by international institutions lie various versions of macroprudential architectures realized by individual countries. Such solutions were shaped by the level of the financial system's sophistication, the government's role, and the central bank's mandate. Yet the dominating trend is to entrust the macroprudential mandate to a central bank, especially if it already has a wide mandate for supervision and regulation of the financial sector. This is especially typical for emerging markets. In most of the reviewed countries, central banks apply macroprudential instruments. The analysis of specificities of the Ukrainian bank-dominated financial system ${ }^{1}$ as well as of international practices points to the most rational solution: to affirm legally the National Bank's macroprudential mandate in the nearest future. Cooperation within the Financial Stability Council should also be further enhanced.
\end{abstract}

\section{JEL Codes: G280, E580}

Keywords: macroprudential mandate, macroprudential authorities, central bank, interagency financial stability boards

\section{INTRODUCTION}

Demand from businesses and the public for financial stability was a legitimate reaction to the global crisis of 2007-2009. We see "financial stability" as a state in which the financial system is capable of performing its key functions efficiently and smoothly, i.e. financial intermediation and arrangement of payments, thus contributing to sustainable economic growth and resilience to crises' impact on economy. Or, as Garry J. Schinasi (2006) summed it up, many researchers define financial stability as the "absence of financial instability."

In order to achieve financial stability, appointed (or newly established) authorities design and implement macroprudential policy (MPP). In other words, the authorities execute a macroprudential mandate (MPM). As we speak of public authorities, their objectives and rights should be laid down in laws (or other legal acts or regulations) according to the basic principle of public law: a public authority can do only those things that it is allowed to do by a body of laws.

Through the last decade, both developed and emerging market countries searched for the optimal framework of bodies responsible for financial stability and reflect this solution in legal acts. It is hard to evaluate these solutions yet: the time that has passed since their implementation is usually too short. ${ }^{2}$ Additionally, there are no commonly accepted units or systems to measure financial stability.

\footnotetext{
${ }^{1}$ Also referred to as bank-centric; that is, banks control the prevailing share in the financial system assets, dominate on capital markets, and distribute the largest proportion of savings in the economy.

${ }^{2}$ There have been certain works lately dedicated to attempts to measure MPP efficiency. The authors tended to concentrate so far mostly on analysis of individual country experiences or efficiency of certain instruments. However, there a new works (Bruno, Shim, and Shin (2015) and Akinci and Olmstead-Rumsey (2015)) that indicate the topic drives attention and is promising for further research.
} 
The need for ensuring financial stability at the global level promoted recommendations on MPM and macroprudential authorities from dedicated international organizations. In particular, the European Systemic Risk Board (ESRB), which is a part of the EU's Single Supervisory Mechanism, and the Financial Stability Board (FSB), a discussion forum of the G20 devoted to consideration of risks and ways for their mitigation at the global scale, should be mentioned. Other international organizations like the IMF, World Bank, and Basel Committee on Banking Supervision also pay close attention to MPMs.

This article attempts to look into a variety of national solutions and international recommendations on the development of macroprudential authorities, to outline global trends and norms, and to compare them with Ukrainian practices.

\section{DEFINING THE MACROPRUDENTIAL MANDATE: LITERATURE AND RECOMMENDATIONS REVIEW}

Previous studies on various MPP aspects established solid grounds for dialogue on MPM and macroprudential authorities. A lot of attention focused on analysis of system of macroprudential authorities/institutional macroprudential framework in works by Borio (2009), CGFS (2010), Goodhart (2011), Ingves (2011), Nier (2009, 2011), Nier and Tressel (2011), Viñals (2011), Nier et al. (2011), Lim et al. (2013), and Brockmeijer et al. (2013). The authors substantiated the need for a clear definition of macroprudential authorities, outlined principles for their work, and considered different configurations of the mandate's distribution between organizations - both with and without an interagency financial stability board.

Macroprudential instruments and application thereof were reviewed in a number of works, e.g. by Borio and Shim (2007), Lim et al (2011), Nier and Osiński (2013), ESRB (2014), Claessens (2014), and Akinci and Olmstead-Rumsey (2015). The works contain recommendations on possible sets of macroprudential instruments, and conditions and objectives for application of each of them.

It should be noted separately that, in spite of the wide use of terms "macroprudential mandate" and "macroprudential authority," inter alia in regulations (including international ones), there is little consensus among researchers across the world on the exact content of these terms. However, the link between these two categories is beyond doubt: "macroprudential authority" is an organization, a board, or a committee that possesses an MPM within a given jurisdiction (while there are still different opinions regarding the real meaning of "macroprudential mandate").

Researchers from the IMF (Osiński, Seal, and Hoogduin, 2013) tend to view the MPM as a right for macroprudential policy. A group of researchers under the Governor of the Swedish Riksbank proceeded from the same understanding (2011). Financial regulators in Slovenia and Cyprus share this vision.

At the same time, researchers from the IMF in several works treat the mandate for ensuring financial stability also as the MPM. The French High Council for Financial Stability has rather resembling views.

On the other hand, experts from the Institute for Monetary and Economic Studies, Egawa, Otan, Sakiyama (2015), differentiate between the terms "financial stability mandate" and "macroprudential mandate." Unfortunately, they do not offer their understanding of the latter term.

The authors of this research tend to distinguish between macroprudential mandates and mandates for ensuring financial stability. They also support the point of view of those researchers who believe that the MPM covers the rights and obligations of a regulatory authority to design and implement MPP.

In spite of these discrepancies in terminology, the process of affirmation and refinement of MPMs gathers steam on a global scale. Back in 2009 at the G20 Summit in London, leaders of key world economies undertook in their final declaration to amend regulatory systems to ensure that authorities "are able to identify and take account of macro-prudential risks across the financial system'. The agenda also included development of macroprudential tools. Basel Committee's Core Principles for Effective Banking Supervision (2012) also mentioned macroprudential authorities and some of their competences.

The EU has advanced the most in setting rules on national macroprudential frameworks and mandates of macroprudential authorities - mostly due to the need to ensure financial stability within the whole integration block. The ESRB was established as a macroprudential authority at the EU level and the ECB received certain macroprudential powers as well. Thus, the ESRB outlined in its recommendation of 2011 the requirements for macroprudential authorities in the EU at the national level. In particular, it emphasized the need for a clearly designated macroprudential authority (a single institution or a board) at the national level and stressed the need to ensure a leading role for a central bank in this framework (especially where the bank is responsible for supervision). 


\section{COMMON FEATURES AND PARTICULARITIES OF NATIONAL MACROPRUDENTIAL MANDATES}

The results of this research covering $67^{3}$ countries from different regions across the world show various national approaches to designation of authorities with an MPM. These decisions were largely conditioned by traditions that existed in financial regulation and public administration in general; they also depended on the structure and specific features of domestic financial markets. In particular, among significant drivers can be a bank-dominated financial system, high institutional capacity building, and independence of the national bank, as well as trust to this central bank.

In regional terms, the following trends were observed (see Figure 1).

\section{Figure 1. Macroprudential authorities (geographical dimension)}

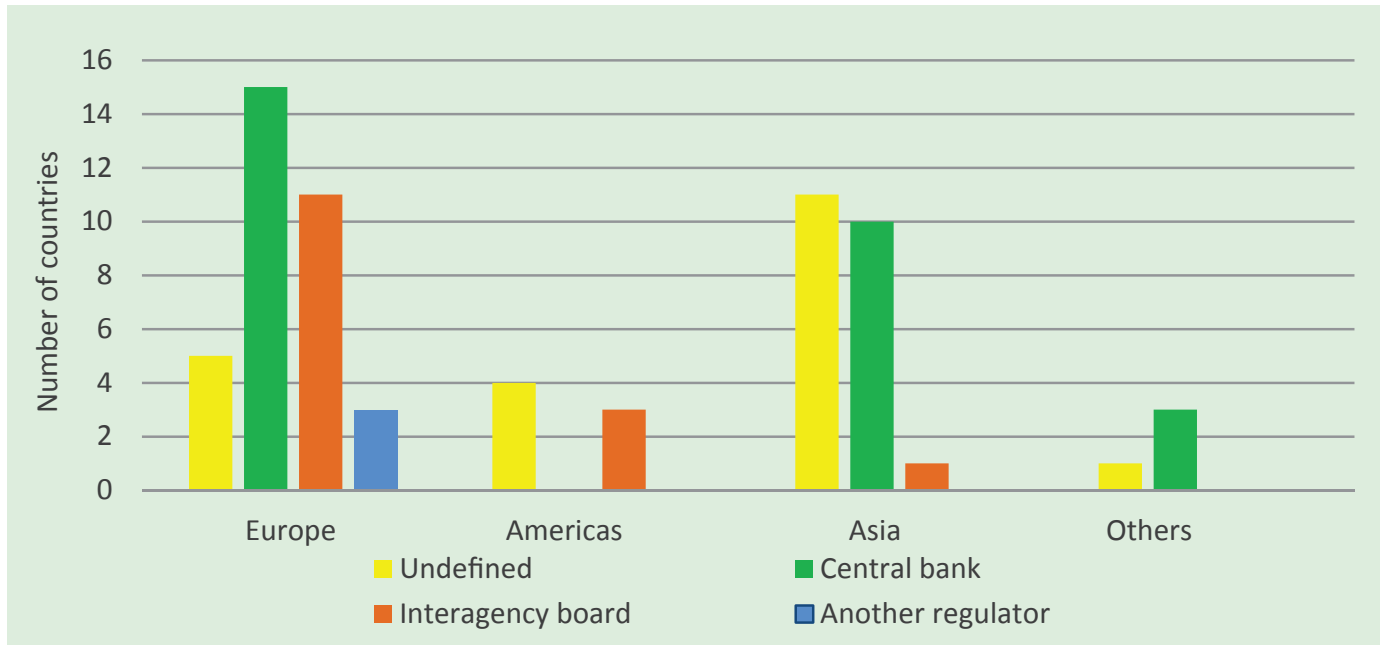

There are not so many countries in Europe where the situation with an MPM remains unsettled. In some of those countries, like Italy and Romania, the respective draft laws have already been submitted to parliaments. MPMs are mostly entrusted to central banks or interagency financial stability boards. Europe is also the only region with the case of other financial regulators as designated macroprudential authorities (the Ministry of Finance or financial supervision authorities, FSAs). Nevertheless, these cases are rather exceptional.

In countries of the Americas covered by the research, the macroprudential authority is either an interagency board (USA, Chile) or not clearly designated (Canada, Brazil).

Almost half of the Asian countries covered by the study did not have a clearly designated macroprudential authority. In most cases, where this issue has been already resolved, the MPM is vested in a central bank and only in some to an interagency board.

In the rest of the countries (in Africa, in Australia, and New Zealand), MPMs were mostly vested in central banks.

The following division was observed in terms of levels of economic development (see Figure 2). The highest heterogeneity in designation of macroprudential authority was discovered among developed economies (OECD countries were taken as a proxy). The most frequent are the cases of designation of a central bank or an interagency financial stability board as a macroprudential authority. As was mentioned above, there are also examples of other financial sector regulators with an MPM in this group of countries (predominantly FSAs, and, in Norway's case, the Ministry of Finance). However, in many of these countries the situation remains unresolved.

${ }^{3}$ In the other three countries (Azerbaijan, Kyrgyzstan, and Vietnam), no signs of a legally outlined MPM or macroprudential tools applied were discovered. Thus, they were not included in further analysis. 


\section{Figure 2. Macroprudential authorities (level of development)}

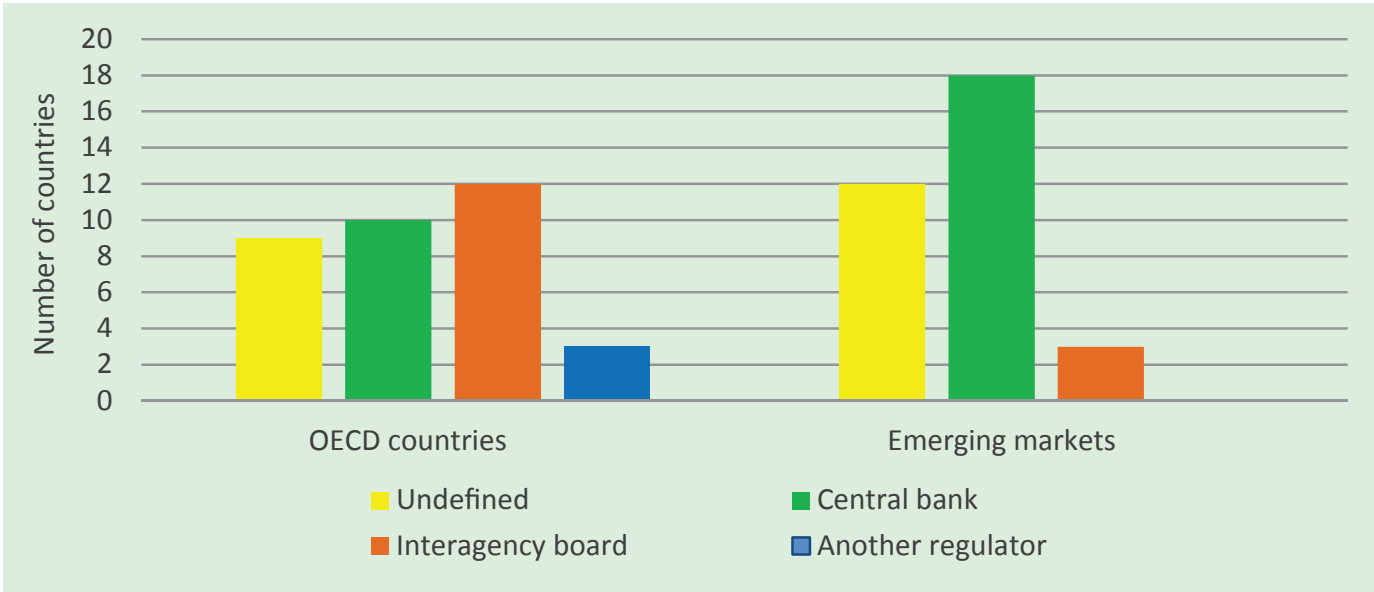

In emerging market economies (like Malaysia, Serbia, or Thailand), the most widespread approach is giving the MPM to a central bank, while designating an interagency board as a macroprudential authority is relatively less common.

There is a growing trend of putting MPMs into law. This is especially typical for the EU. In 29 out of 30 European countries covered with officially designated macroprudential authorities, the MPM is outlined in laws. In many cases, amendments are made to legal acts already in force, especially if a central bank is vested with the MPM. At the same time, there is a widening practice in recent years of the adoption of new dedicated "macroprudential laws." This is mostly the case where a board became the macroprudential authority, ${ }^{4}$ e.g. in Croatia, Germany, Slovenia (all laws in 2013), Iceland (2014), Luxembourg, and Poland (2015).

Another interesting aspect is a dependence of the MPM's distribution on the role of the central bank in the area of supervision and regulation of financial sector.

The results of the study suggest that the wider the mandate a central bank has (especially for supervision), the more likely it is given the MPM (see Table 1). Such distribution is in line with recommendations of the ESRB and the IMF. On all occasions when a central bank is a megaregulator, ${ }^{5}$ it is also a macroprudential authority. However, in Estonia and Lithuania, central banks received MPMs in spite of having no mandate even for banking sector supervision. One of the reasons behind this phenomenon is probably the experience gained by central banks in the area financial sector analysis as well as the institutional capacity traditionally associated with them.

It is also interesting to compare the national approaches to MPM distribution and the framework of financial stability boards.

\section{Table 1. Correlation between the MPM and the central bank's mandate for supervision}

\begin{tabular}{|c|c|c|c|c|}
\hline & & \multicolumn{3}{|c|}{ Central bank's mandate for financial sector regulation } \\
\hline & & none & (partial) banking regulator & megaregulator \\
\hline \multirow{6}{*}{ 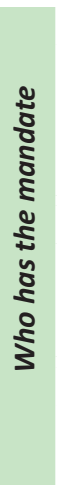 } & & 2 & 16 & 10 \\
\hline & $\begin{array}{l}\text { central bank } \\
\text { (28) }\end{array}$ & Estonia, Latvia & $\begin{array}{c}\text { Albania, Belgium, Cyprus, Greece*, Indo- } \\
\text { nesia, Ireland, Malta, Malaysia, Mongolia, } \\
\text { Nigeria, New Zealand, Portugal, Qatar, SAR, } \\
\text { Thailand, the UK* }\end{array}$ & $\begin{array}{c}\text { Armenia, Czech Republic, } \\
\text { Georgia, Hungary, Kazakhstan, } \\
\text { Lithuania, Oman, Serbia, Singa- } \\
\text { pore, Slovakia }\end{array}$ \\
\hline & \multirow[b]{2}{*}{$\begin{array}{l}\text { interagency } \\
\text { board (15) }\end{array}$} & 6 & 9 & 0 \\
\hline & & $\begin{array}{l}\text { Austria, Denmark, } \\
\text { Germany, Iceland, Lux- } \\
\text { embourg, Poland }\end{array}$ & $\begin{array}{l}\text { Bulgaria, Chile, Croatia, France*, the } \\
\text { Netherlands, Slovenia, Turkey, Uruguay, USA }\end{array}$ & - \\
\hline & \multirow{2}{*}{$\begin{array}{l}\text { other } \\
\text { regulators (3) }\end{array}$} & 2 & 1 & 0 \\
\hline & & $\begin{array}{l}\text { Sweden (FSA), } \\
\text { Finland (FSA) }\end{array}$ & Norway (Ministry of Finance) & - \\
\hline
\end{tabular}

\footnotetext{
${ }^{4}$ In most cases when an MPM was given to a central bank, the amendments are made to a current law on central bank

${ }^{5}$ Responsible for regulation of the entire financial system, not only the banking sector.
} 
Significantly, most of the countries studied have some interagency financial stability boards (councils, committees) or at least there exists some sort of memorandum on cooperation between financial sector regulators (in states where a central bank is also a megaregulator, the role of interagency boards is often taken over by internal financial stability committees) (see Table 2). As a rule in developed economies (OECD countries), interagency boards (if there any) are chaired by a representative of the government (by the Minister of Finance in most cases). At the same time, special rights and prerogatives of a central bank are protected within such boards (e.g., a veto right or the exclusive right to initiate application of macroprudential instruments in Germany). In all instances, central banks supply information and analytical support to the boards.

\section{Table 2. Who chairs interagency boards?}

\begin{tabular}{|c|c|c|c|c|c|}
\hline & $\begin{array}{c}\text { no interagency FS } \\
\text { board (14) }\end{array}$ & $\begin{array}{c}\text { central bank chairs } \\
\text { interagency FS board (21) }\end{array}$ & $\begin{array}{l}\text { FSA chairs } \\
\text { interagency } \\
\text { FS board (1) }\end{array}$ & $\begin{array}{l}\text { government chairs in- } \\
\text { teragency FS board (24) }\end{array}$ & $\begin{array}{c}\text { rotating } \\
\text { chairmanship } \\
\text { (6) }\end{array}$ \\
\hline & 6 & 5 & 0 & 1 & 0 \\
\hline \multirow[t]{2}{*}{$\begin{array}{l}\text { central bank - } \\
\text { megaregulator } \\
\text { (13) }\end{array}$} & $\begin{array}{l}\text { Armenia, Bahrain, } \\
\text { Czech Republic, } \\
\text { Georgia, Lithuania, } \\
\text { Singapore }\end{array}$ & $\begin{array}{l}\text { Belarus, Hungary, Ka- } \\
\text { zakhstan, Oman, Serbia }\end{array}$ & - & Russia & - \\
\hline & 6 & 14 & 0 & 15 & 4 \\
\hline \multirow[t]{2}{*}{$\begin{array}{l}\text { central bank - } \\
\text { banking } \\
\text { regulator (39) }\end{array}$} & $\begin{array}{l}\text { Belgium, Ireland, } \\
\text { Israel, Saudi Arabia, } \\
\text { UAE, UK }\end{array}$ & $\begin{array}{c}\text { Australia, Croatia, } \\
\text { Cyprus, Malaysia, Malta, } \\
\text { Nigeria, Netherlands, Phil- } \\
\text { ippines, Portugal, Qatar, } \\
\text { Romania, SAR, Slovenia, } \\
\text { Thailand }\end{array}$ & - & $\begin{array}{c}\text { Albania, Argentina, } \\
\text { Bulgaria, Chile, France, } \\
\text { Greece, Hong Kong, India, } \\
\text { Italy, Korea, Norway, Spain, } \\
\text { Turkey, Uruguay, USA }\end{array}$ & $\begin{array}{c}\text { Brazil, } \\
\text { Indonesia*, } \\
\text { Mongolia, New } \\
\text { Zealand }\end{array}$ \\
\hline & 2 & 2 & 1 & 8 & 2 \\
\hline $\begin{array}{c}\text { central bank } \\
\text { w/o supervision } \\
\text { mandate (15) }\end{array}$ & $\begin{array}{l}\text { Japan, Switzer- } \\
\text { land }\end{array}$ & Latvia, Denmark** & Austria & $\begin{array}{c}\text { Canada**, China, } \\
\text { Estonia, Germany, Iceland, } \\
\text { Luxembourg**, Mexico, } \\
\text { Sweden }\end{array}$ & $\begin{array}{l}\text { Poland, } \\
\text { Finland }\end{array}$ \\
\hline
\end{tabular}

In emerging market economies, the prevailing trend is that a central bank representative chairs the board (committee or council). Rotation of chairpersons is a rare practice in both groups of countries (see Figure 3 and 4).

\section{Figure 3. Who chairs interagency FS board, developed markets (OECD countries)}

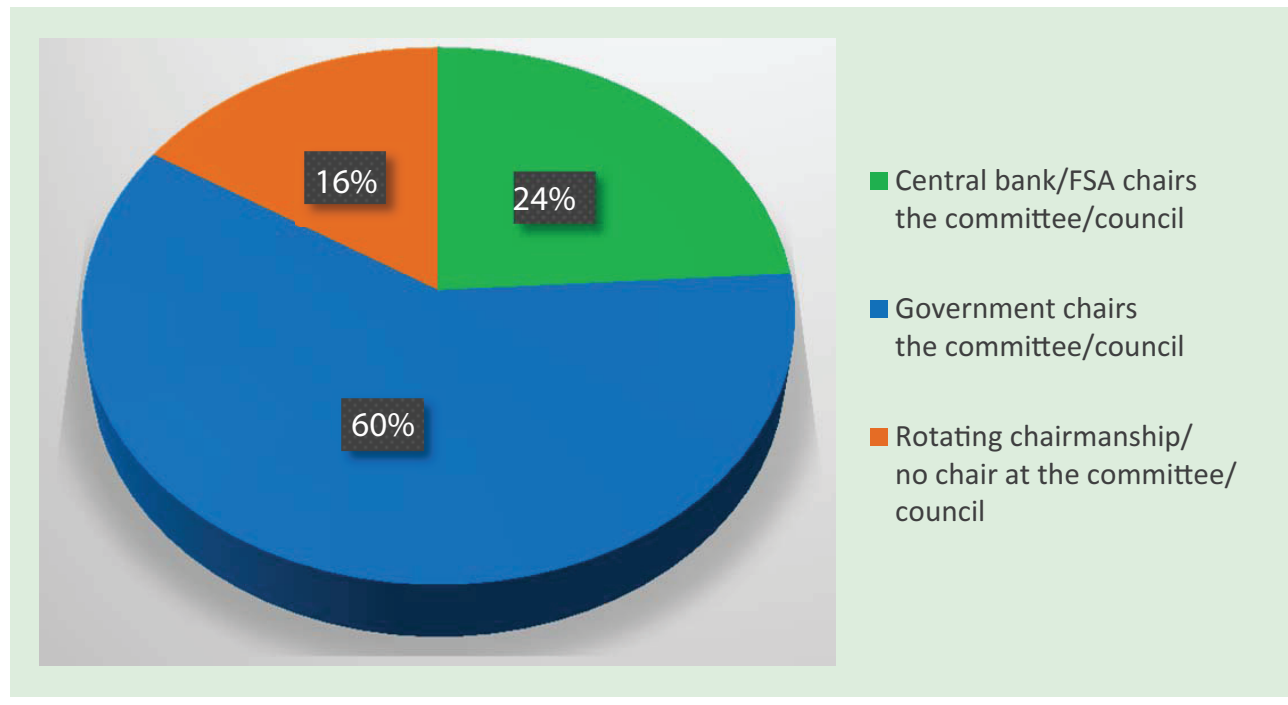

Note: Austria's case (FSA as a chair) is put into the "central bank/FSA chairs the committee/council" category. Cases where the chair changes depending on the economic cycle (crisis or "normal times" - Polish example) is categorized as "rotating chairmanship...". 


\section{Figure 4. Who chairs interagency FS board, emerging markets}

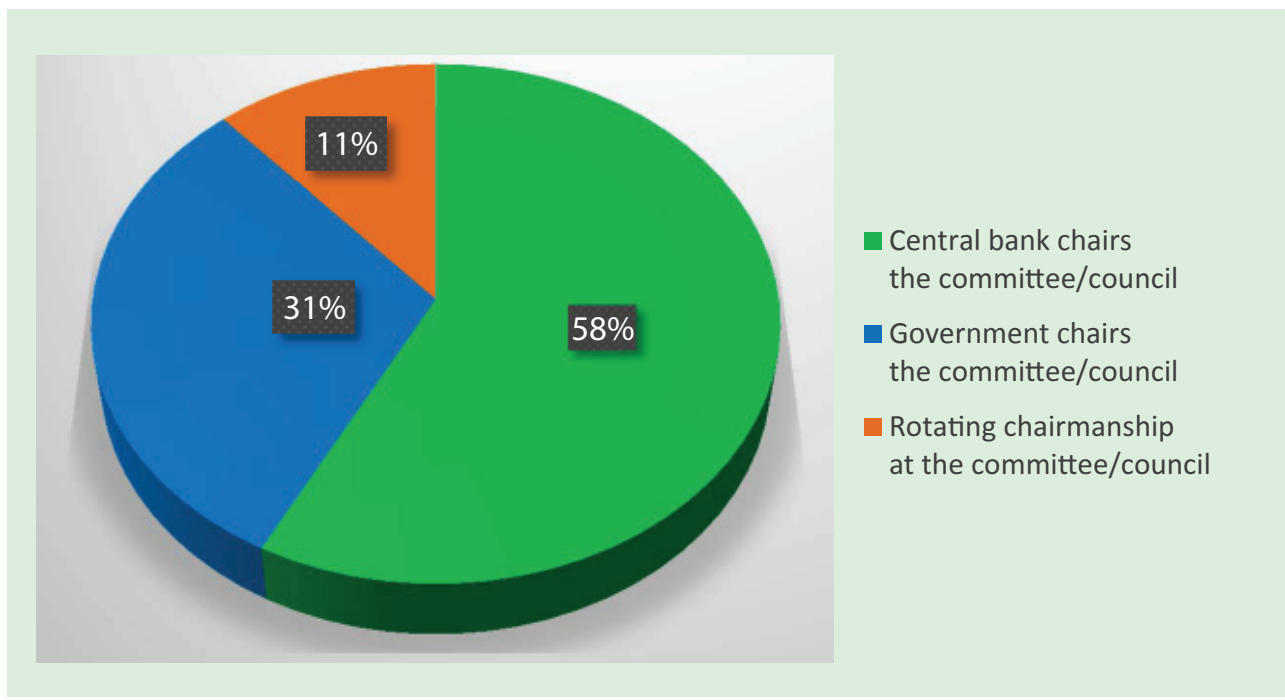

However, the existence of an interagency financial stability board (observed in 53 countries) was not a decisive factor for the process of designation of a macroprudential authority (see Figure 5). Thus, although establishment of a financial stability boards is a widespread practice, their role within macroprudential framework varies depending on national conditions.

\section{Figure 5. Macroprudential mandates in countries with an interagency financial stability board (53)}

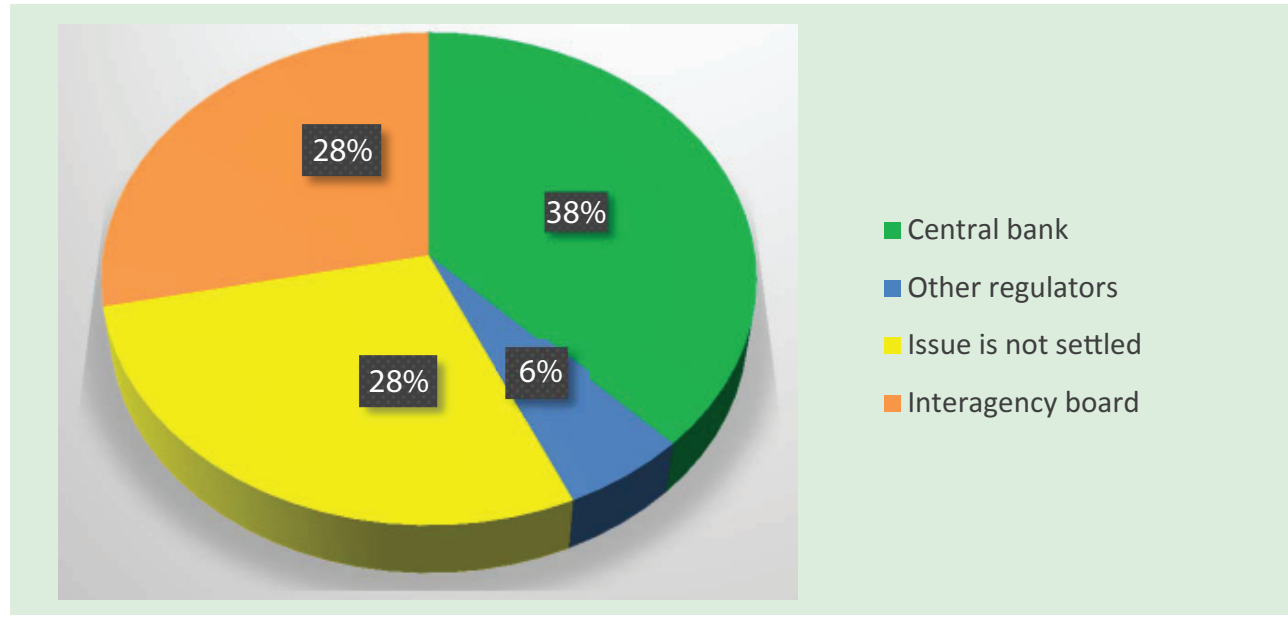

Another matter closely related to MPM is the application of macroprudential instruments ${ }^{6}$ (see Figure 6 ). In most of the reviewed cases, central banks are the authorities that apply macroprudential instruments - in 40 out of 67 countries (both in countries where central banks have an MPM and in economies where the situation is not yet formally settled). There are also numerous cases of application of macroprudential instruments by FSAs. However, a division of responsibilities for financial stability was observed between regulators in many countries. The division takes the shape of either allotting macroprudential instruments to mandates of different regulators or the establishment of multi-stage procedures that involves both the initiating institution and a collective (interagency) financial stability board.

\footnotetext{
${ }^{6}$ In order to ensure compatibility of comparisons, the study concentrates on Basel III macroprudential instruments.
} 


\section{Figure 6. Who applies macroprudential instruments}

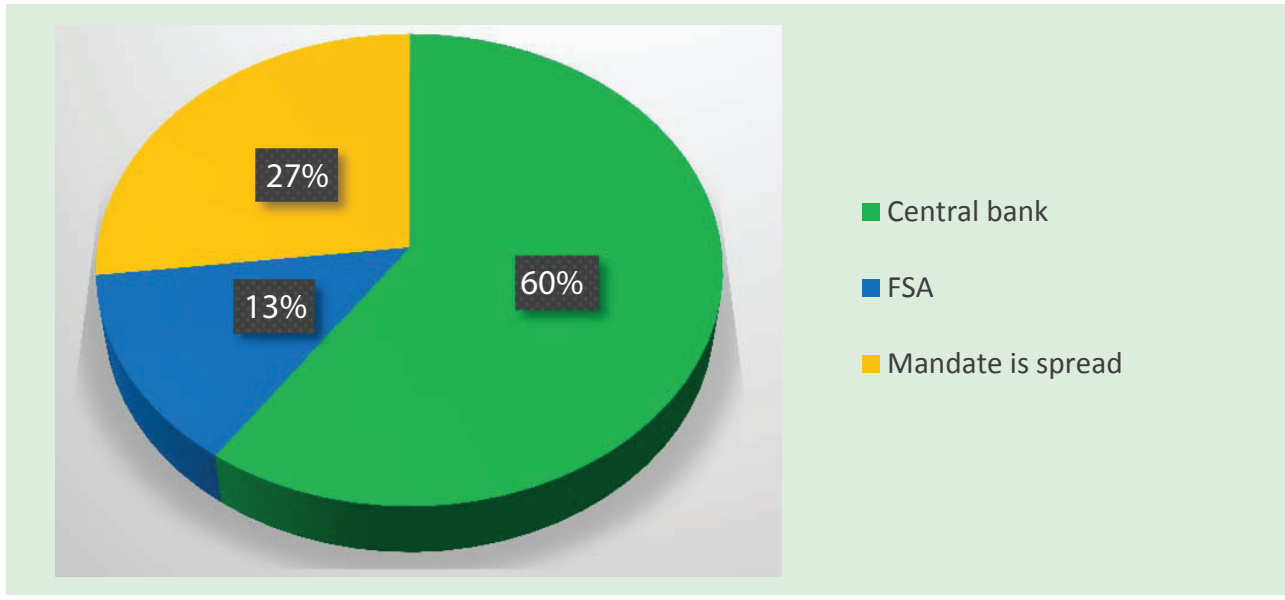

There are several practical ways of incorporating the mandate for application of macroprudential instruments into the legal system: either through a dedicated law on macroprudential supervision, or a separate law on banking (financial) supervision, or via a (internal) by-law by the regulator. The EU member states stand out, however, as they are obliged to implement EU directives, as well as mechanisms stipulated by EU regulations, into national legislation. Thus, the mandates to apply macroprudential instruments have to be put into law.

In some cases, the situation with rights to apply macroprudential instruments is rather intricate. A new Polish law presents an interesting example of the division of macroprudential competences, including the rights to apply macroprudential instruments (see Figure 7). The law divides the powers to initiate, to approve, and to apply the instruments between regulators at different levels. A regulator may initiate application of a tool within its competence as stipulated by law and submit its proposal to the Financial Stability Committee. If the decision of the Committee is positive, the regulator applies the instrument. On one hand, this framework establishes a system of checks and balances between regulators and promotes joint balanced decisions. On the other hand, the system may prove to be too rigid and complex to ensure timely solutions for crisis situations.

\section{Figure 7. Macroprudential framework in Poland}

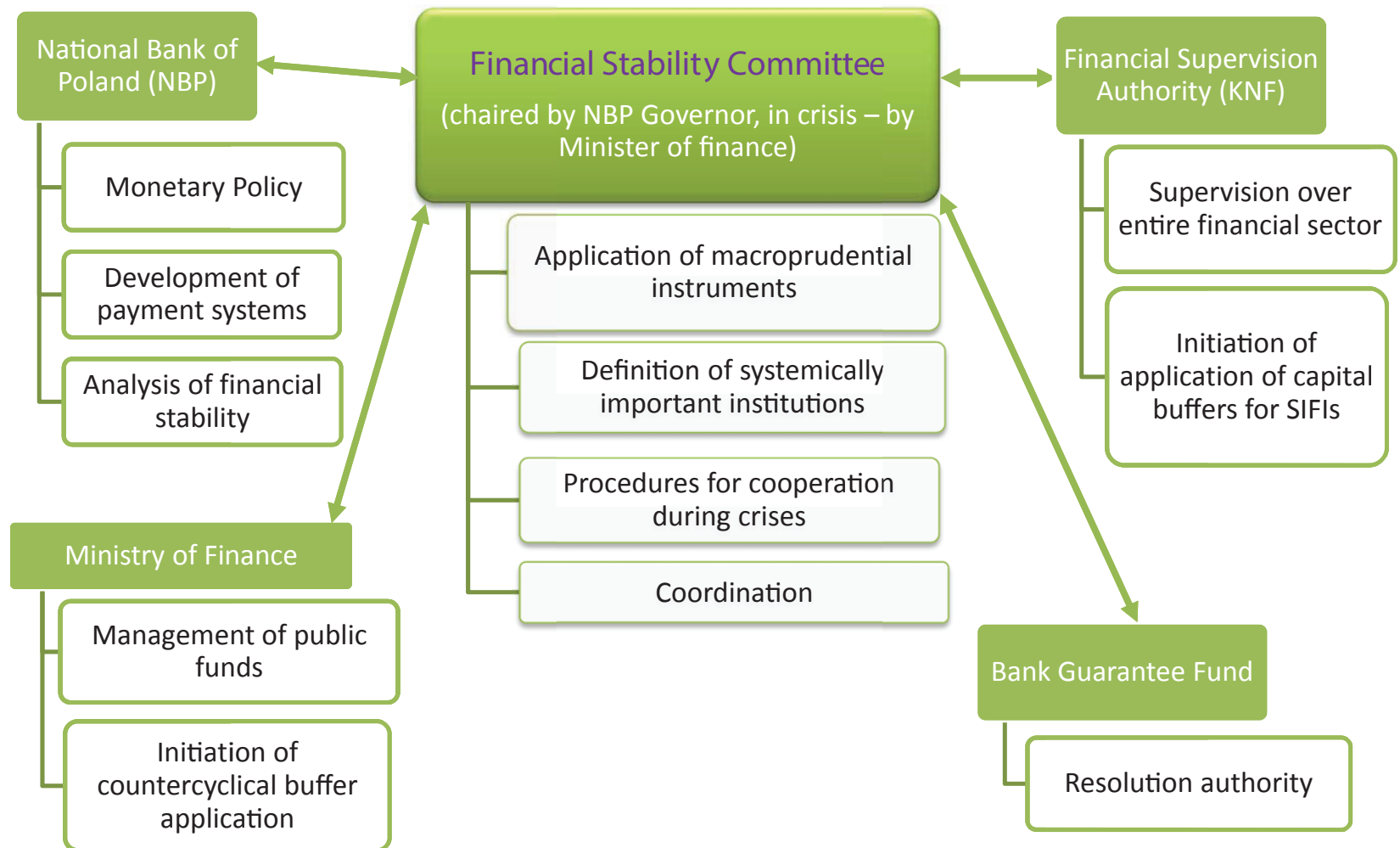


At the same time, initiation and making decisions on application of macroprudential instruments is concentrated within central banks in the Czech Republic and the Slovak Republic. This focuses responsibility on one regulator (thus making the entire framework more transparent) and promotes more expedient decision-making.

Therefore, in spite of regional and national economic and political differences between the countries, the factors taken into account while making a policy decision on the designation of macroprudential authority normally are the national model of the financial system, the real scope of powers, and level of independence and institutional capacity of financial regulators. The fact of whether or not the country has an interagency financial stability board in many cases was not a decisive factor for designation of an authority with an MPM.

\section{SITUATION IN UKRAINE: INSTITUTIONAL FRAMEWORK IS ESTABLISHED. WHAT'S NEXT?}

As of today, the NBU de-facto performs the mandate for ensuring financial stability in Ukraine.

Part 3 of Article 6 of the Law of Ukraine On the National Bank of Ukraine stipulates in particular that, "The National Bank shall promote, within the limits of its authority, financial stability, including stability of the banking system, without prejudice to the objective set forth in the second part of this article" (i.e., securing price stability). The wording was adopted only in 2015. Similar to most central banks, the NBU proceeds with a priority of achieving and securing price stability, but it also pays close attention to the state of the financial system in general and to analysis and mitigation of risks that undermine its resilience. Therefore, the function of analysis of financial stability is mentioned now in articles 7 and 57 of the current Law On the National Bank of Ukraine.

Another body with a mandate in the area of financial stability is the Financial Stability Council (the Council hereinafter). It was established by Presidential Decree No. 170 of 24 March 2015. The Council comprises heads of the NBU, the Ministry of Finance, the Deposit Guarantee Fund, and two financial market regulators (National Commission for Securities and Stock Market and National Commission for State Regulation of Financial Services Markets). The choice of members is logical. First, the members have influence on virtually all key processes in the financial system. Second, the absence of outsiders promotes in-depth professional discussions, minimizes political interest towards the work of the body, and prevents leaks of sensitive information.

In line with best international practices, the Council considers only systemic risks. These risks threaten to destabilize the functioning of the entire financial sector rather than to undermine the work of individual institutions (regardless of their size). Typical examples of systemic risks include sharp increases in public debt, substantial drops of prices in global commodity markets, and growing "bubbles" on some markets.

It should be noted that the Council is a platform for professional discussion, not a decision-making center or public authority. ${ }^{7}$ Any (even the slightest) pressure from politicians would only impede an impartial exchange. The Council does not compromise mandates of its member-institutions and does not interfere with activities of other public authorities. The Council may only recommend certain measures based on its deliberations. The addressee of a recommendation has to either comply or explain its reasons behind its failure to comply, which is in line with the common European "act or explain" principle.

Other regulators (National Commission for Securities and Stock Market and National Commission for State Regulation of Financial Services Markets) have no legal mandate for promoting financial stability (not to mention an MPM) despite their stake in financial stability and certain powers that can influence it. Thus, their formal influence over financial stability is limited to participation in the Council.

The Council has held seven meetings so far. At these meetings, the Council traditionally reviewed systemic risks to the stability of the financial system and economy in general and discussed a few acute issues that required coordination of regulators' efforts. No formal recommendations were developed up until now, mostly because the interagency board continues to study international experiences and makes efforts to construct the "proper format." However, frank and substantial exchanges in the Council format facilitated certain decisions with material results. In particular: the guidelines for transformation of state-

\footnotetext{
${ }^{7}$ The power of the Council to make decisions in the presence of signs of unstable financial conditions of the banking system or the emergence of circumstances threatening the resilience of Ukraine's banking/financial system can be considered as a certain exception from the general rule. Such a decision gives the NBU authority to set temporary special requirements in regulation and supervision over banks and other entities subject to NBU supervision (Article 71 of the Law of Ukraine On the National Bank of Ukraine). However, taking into account that this item extends the NBU's authority and does not limit it, one can argue that this regulation is in line with the mentioned principle.
} 
owned banks were refined; the Deposit Guarantee Fund received additional funding of UAH 21.5 billion from the Government in late 2015 to cover pay-outs to depositors at the banks that went bankrupt; and key prerequisites were ensured allowing the NBU to launch a new monetary regime - inflation targeting.

At the moment, given current tasks, the absence of a legally affirmed MPM in Ukraine should not be viewed as a serious hold-back for financial sector supervision (including macroprudential supervision). The NBU already has the powers necessary to analyze and monitor financial stability and to apply prudential tools for macroprudential purposes. However, the efficiency of the NBU's financial stability policy is limited if risks emerge beyond the banking sector's perimeter. In such situations, the NBU has to rely on the institutional capacity of other financial regulators and efficient cooperation with them. The steps for consolidation of financial supervision planned at the national level will only partially relax these limitations.

Given Ukraine's European aspirations (and thus ESRB recommendations), the global trends in financial sector development, as well as plans for further development of a macroprudential toolkit, defining a legally affirmed MPM becomes the most desirable scenario.

\section{CONCLUSIONS AND RECOMMENDATIONS}

While defining the MPM in Ukraine, the following factors should be considered:

- The Ukrainian financial sector is bank-centric (dominated by banks). The share of the banking system in total financial system assets was around $80 \%$ in 2015.

- The NBU now regulates and supervises the banking sector and ensures the oversight of payment systems. The supervisory mandate of the NBU will be further expanded once the law on consolidation of financial supervision ${ }^{8}$ is adopted and the functions of National Commission for State Regulation of Financial Services Markets are split.

- The NBU accumulated the most extensive experience of financial stability analysis (over the entire financial sector) among Ukrainian regulators. It possesses the necessary knowledge and skills on processes in the financial sector, macro- and microdata, and adequate instruments, including a modeling toolkit and organizational capacity.

- The NBU is de jure and de facto Ukraine's most independent financial sector regulator.

- The Financial Stability Council works in Ukraine for the second year. It has a mandate for both crisis prevention and crisis management. The Council members possess necessary information on all segments of the financial system and are directly responsible for their regulation. Organizational and analytical support for the Council is provided by the secretariat working within the Financial Stability Department of the NBU.

Upon receiving a mandate for regulation of a wider range of financial institutions (which should be transferred from the National Commission for State Regulation of Financial Services Markets), the NBU will approach the status of a financial megaregulator. Given that and taking into account the aforementioned arguments and with regard to international practices, we believe that it is necessary to formally (legally) vest the MPM in the NBU. This step will also be in line with the ESRB recommendations. For this, it will suffice to make amendments to the existing Law On the National Bank of Ukraine.

At the same time, the Financial Stability Council shall remain an important platform for cooperation between financial regulators. Moreover, given the consolidation of financial supervision and the need for enhanced coordination of regulators' actions, there might be an emerging call for extension of the Council's mandate and functions. In particular, this may relate to coordinated control measures to mitigate cross-sectoral systemic risks. 


\section{References}

- Act of the Republic of Croatia (2013). Act on the Financial Stability Council. OG 159/2013.

- Act of the Republic of Poland (2015). Ustawa o nadzorze makroostrożnościowym nad systemem finansowym i zarządzaniu kryzysowym w systemie finansowym. Uchwalono na pos. nr 98 dnia 05-08-2015, Dz.U. poz. 1513.

- Act of the Republic of Slovenia. Zakon o makrobonitetnem nadzoru finančnega Sistema. Uradni list RS, št. 100/13.

- Act on Monitoring Financial Stability (Financial Stability Act) - Gesetz zur Überwachung der Finanzstabilität (Finanzstabilitätsgesetz) in the wording of the announcement of 28 November 2012 (Federal Law Gazette I, page 2369) as last amended by Article 2 paragraph 36 of the Act of 1 April 2015 (Federal Law Gazette I, p. 434).

- Act on the Financial Stability Council (2014). Iceland, No. 66, dated 28 May 2014.

- Arvai Z., Prasad A., Katayama K. (2014). Macroprudential Policy in the GCC Countries. IMF Discussion note, No. SDN/14-01. https://doi.org/10.5089/9781484334430.006

- Bank of Slovenia. Macroprudential Policy for the Banking Sector - Strategic Framework.

- Basel Committee on Banking Supervision (2012). Core Principles for Effective Banking Supervision.

- Bank for International Settlements (2011). Central bank governance and financial stability. A report by a Study Group chaired by Stefan Ingves.

- Borio C., Drehmann M. (2009). Towards an operational framework for financial stability: fuzzy measurement and its consequences. Working Paper, No. 284, BIS.

- Borio C., Shim I. (2007). What can (macro-) prudential policy do to support monetary policy? Working Papers, No. 242, BIS.

- Bruno V., Shim I., Song Shin H. (2015). Comparative assessment of macroprudential policies. Working Papers, No. 502, BIS.

- Claessens S. (2014). An Overview of Macroprudential Policy Tools, Working Paper, No. 14-214, IMF.

- Committee on the Global Financial System (2010). Macroprudential instruments and frameworks: a stocktaking of issues and experiences. CGFS Papers, No. 38.

- Egawa E., Otani A., Sakiyama T. (2015). What Determines Institutional Arrangements for Macroprudential Policy? Discussion Paper Series, No. 2015-E-3, IMES.

- ESRB (2011). Recommendation on the macro-prudential mandate of national authorities. No. ESRB 2011-3.

- ESRB (2014). Recommendation on the macro-prudential mandate of national authorities. Follow-up Report - Overall assessment, No. ESRB 2011-3.

- ESRB (2014). The ESRB Handbook on Operationalising Macro-prudential Policy in the Banking Sector.

- ESRB (2015). National competent or designated authorities for CRD IV/CRR instruments and current or future implementation of macroprudential instruments.

- G20 London Summit (2009). Declaration on Strengthening the Financial System.

- Goodhart C. (2011). The Macro-Prudential Authority: Powers, Scope and Accountability. OECD Journal: Financial Market Trends, Vol. 2011, No. 2.

- Gramegna P. (2015). Loi du 1er avril 2015 portant création d'un comité du risque systémique et modifiant la loi modifiée du 23 décembre 1998 relative au statut monétaire et à la Banque centrale du Luxembourg. Journal Officiel du GrandDuché de Luxembourg, No. 64, p. 1294.

- IMF (2011). Macroprudential Policy: An Organizing Framework, Monetary and Capital Markets Department, approved by José Vi-als.

- Jansen B., Bossu W., Arda A., Knight D., Tamez M., Kroytor O., Gianviti F., Hockett R. (2013). Implementing Macroprudential Policy - Selected Legal Issues, IMF. 
- Liebeg D., Posch M. (2011). Macroprudential Regulation and Supervision: From the Identification of Systemic Risks to Policy Measures. Finanzmarktstabilitätsbericht, Oesterreichische Nationalbank.

- Lim C.H., Krznar I., Lipinsky F., Otani A., Wu X. (2013). The Macroprudential Framework: Policy Responsiveness and Institutional Arrangements. Working Paper, No. 13-166, IMF.

- Lim C., Columba F., Costa A., Kongsamut P., Otani A., Saiyid M., Wezel T., Wu X. (2011). Macroprudential Policy: What Instruments and How to Use Them? Lessons from Country Experiences. Working Paper, No. 11-238, IMF.

- Masahiro K., Morgan P. (2012). Central Banking for Financial Stability in Asia. Policy Research Institute, Ministry of Finance of Japan, Public Policy Review, Vol. 8, No. 3.

- Nier E. (2009). Financial Stability Frameworks and the Role of Central Banks: Lessons From the Crisis, Working Paper, No. 09-70, IMF.

- Nier E., Osiński J. (2013). Key Aspects of Macroprudential Policy. IMF.

- Nier E., Osiński J. (2013). Key Aspects of Macroprudential Policy. Background Paper, IMF.

- Nier E., Osiński J., Jácome L.I., Madrid P. (2011). Institutional Models for Macroprudential Policy. Discussion note, No. SDN/11-18, IMF. https://doi.org/10.5089/9781463926533.006

- Nier E., Osiński J., Jácome L.I., Madrid P. (2011). Towards Effective Macroprudential Policy Frameworks: An Assessment of Stylized Institutional Models. Working Paper, No. 11-250, IMF. https://doi.org/10.5089/9781463923327.001

- Osiński J., Seal K., Hoogduin L. (2013). Macroprudential and Microprudential Policies: Toward Cohabitation. Discussion note, No. SDN 13-05, IMF.

- Ozge A., Olmstead-Rumsey J. (2015). How Effective are Macroprudential Policies? An Empirical Investigation. International Finance Discussion Papers, No. 1136.

- Salim M.D., Wu X. (2015). Experiences with Macroprudential Policy - Five Case Studies. Working Paper, No. 15-123, IMF.

- Schinasi G. (2006). Safeguarding Financial Stability: theory and practice. IMF, Washington, D.C.

- Vinals J. (2011). The Do's and Don'ts of Macroprudential Policy, European Commission and ECB Conference on Financial Integration and Stability. Brussels, 2 May 2011. 